\title{
Polyadenylation and reverse transcription of influenza viral RNA
}

\section{J.S.Emtage, G.H.Catlin and N.H.Carey}

Searle Research Laboratories, Lane End Road, High Wycombe, Bucks., HPi 2 4HL, UK

Received 21 February 1979

\section{ABSTRACT}

The polyadenylation of Fowl Plague Viral RNA and of Influenza A/Victoria Viral RNA using E.coli poly(A) polymerase and the subsequent reverse transcription of the polyadenylated species is reported. We have shown that all 8 genome fragments are adenylated and that an average of 25-30 adenylic acid residues per molecule is sufficient for maximal transcription with reverse transcriptase. The cDNA product is $95 \%$ sensitive to S1-nuclease and hybridisation analysis against viral RNA reveals it to be a faithful copy of the RNA. Amongst the transcription products are long, discrete copies of genes $1-8$, the lengths of which are comparable with those of the vRNA determined by electrophoresis on formamide acrylamide gels. These single-stranded cDNAs have been further transcribed to form double-stranded products with hair-pin structures at one end. Analysis of this material on native acrylamide gels revealed some DNA bands corresponding to the predicted sizes for genes 4-8.

\section{INTRODUCTION}

The Influenza A Viruses are members of the Orthomyxovirus group (1) and have a segmented genome consisting of eight unique single-stranded RNA molecules of molecular weights between $2 \times 10^{5}$ and $10^{6}$. These RNAs lack infectivity and must be replicated during infection to produce both viral mRNA and templates for further vRNA synthesis (2). The mRNAs for Influenza Virus proteins have been extensively studied and shown to produce virus-specified polypeptides in ce11-free protein synthesising systems (3). Further, the genomes for a number of Influenza A Viruses have now been mapped and the genes for most of the virus-specified proteins identified $(4,5,6)$.

Thus, the nature of the genome provides a unique system for studying the relationship between structure and function for eight individual genes and it is already becoming clear that there are regions of similarity, not only among genes of a given strain of virus, but between strains. Skehel and Hay (7) have recently shown the first thirteen nucleotides of the 5'-end of all eight genome RNAs of FPV and of the antigenically unrelated X-31 Influenza 
Virus to be the same. As well, they show that the $5^{\prime}$-termini of the RNA transcripts produced in vitro are similar for the first twelve nucleotides.

To study the nucleotide structure of the genome further, we have investigated the synthesis of DNA complementary to the vRNA. In this publication, we describe the polyadenylation and transcription of vRNA from two strains of Influenza A Virus, properties of the resulting cDNA and synthetic genes, and make a reassessment of the sizes of the vRNAs themselves.

\section{MATERIALS AND METHODS}

Virus

The Rostock strain of Fowl Plague Virus (FPV) was grown in 10-day-old embryonated hens' eggs at $37^{\circ} \mathrm{C}$ for $18-30 \mathrm{hr}$. The allantoic fluid was collected and centrifuged at 2,000 rpm for $10 \mathrm{~min}$ to remove red cells and other cellular debris. Virus was then harvested from the resulting supernatant by centrifugation at $18,000 \mathrm{rpm}$ for $90 \mathrm{~min}$ (IEC B-60, $6 \times 250 \mathrm{ml}$ angle rotor). Virus pellets were resuspended in NTE (100 mM NaCl, $10 \mathrm{mM}$ Tris- $\mathrm{HCl} \mathrm{pH} 7.5$, $1 \mathrm{mM}$ EDTA) by gentle homogenisation, spun at 5,000 $\mathrm{rpm}$ for $4 \mathrm{~min}$ (Sorvall) to remove aggregated yolk protein, and the supernatant removed. The virus was finally purified on a $15 \%-60 \% \mathrm{w} / \mathrm{v}$ linear sucrose gradient in NTE by banding to equilibrium at $24,000 \mathrm{rpm}$ for $3 \mathrm{hr}$ at $4^{\circ} \mathrm{C}$. The virus band, appearing about $1 / 3$ from the bottom of the tube, was removed by suction, diluted to twice its volume with NTE, and pelleted at $25,000 \mathrm{rpm}$ for $40 \mathrm{~min}$ at $4^{\circ} \mathrm{C}$.

Influenza A/Victoria/75 was supplied by Evans Medical Co., Liverpool. RNA extraction

a) FPV:

The pellet of virus was resuspended in $5 \mathrm{ml} \mathrm{NTE}$, SDS added to $0.2 \%$ and the mixture extracted with phenol and chloroform as described (8). The final aqueous phase was made to $200 \mathrm{mM}$ with $\mathrm{NaCl}$ and RNA precipitated by the addition of 2.5 volumes of ethanol. Ethanol precipitates were pelleted $(11 \mathrm{~K} \times 20$ min, Sorval1), washed with ethanol, dried in vacuo and dissolved in TE (10 mM Tris- $\mathrm{HCl} \mathrm{pH} 7.5,1 \mathrm{mM}$ EDTA). RNA was quantitated assuming that $1 \mathrm{mg} / \mathrm{ml}=20$ $\mathrm{A}_{260}$.

b) A/Victoria:

To $10 \mathrm{~m} 1$ virus suspension (at $4 \mathrm{mg}$ protein $/ \mathrm{m} 1$ ) was added an equal volume of $0.4 \% \mathrm{SDS}, 20 \mathrm{mM}$ EDTA. The mixture was extracted with $20 \mathrm{~m} 1$ of phenol and $20 \mathrm{ml}$ of chloroform. After phase separation, the organic layer was re-extracted with $5 \mathrm{ml}$ NTE. The two aqueous phases (plus interfaces) were pooled and 
extracted twice with equal volumes of chloroform. RNA was finally precipitated by the addition of $2 \frac{1}{2}$ volumes of ethanol.

Ethanol precipitates were pelleted, dissolved in $1 \mathrm{ml} \mathrm{TE}$ and spun (10K $x 10 \mathrm{~min}$, Sorval1) to remove insoluble material. Viral RNA was re-precipitated by the addition of 3 volumes of $4 \mathrm{M} \mathrm{NaCl}$. After standing at $-20^{\circ} \mathrm{C}$ for $16 \mathrm{hr}$, the RNA was again pelleted, washed with $70 \%$ ethanol, dried and dissolved in $\mathrm{TE}$.

Enzymes

Reverse transcriptase was isolated as described (9) from AMV-infected plasma supplied through the office of Program Resources and Logistics, Viral

Cancer Program, National Cancer Institute, Bethesda, Maryland, U.S.A. Poly(A) polymerase was isolated (10) from late- $\log$ E.coli B cells (Miles Laboratories). S1-nuclease was prepared by the method of Vogt (11).

Polyadenylation

Viral RNA was polyadenylated at $37^{\circ} \mathrm{C}$ for the indicated times. The reaction mixture contained $50 \mathrm{mM}$ Tris $-\mathrm{HCl} \mathrm{pH} 8,10 \mathrm{mM} \mathrm{MgCl}{ }_{2}, 1 \mathrm{mM} \mathrm{MnCl}{ }_{2}, 50 \mu \mathrm{g} / \mathrm{ml}$ purified ovalbumin, $0.1 \mathrm{mM}{ }^{3} \mathrm{H}$ ATP $(5 \mu \mathrm{Ci} / \mathrm{ml}$ unless otherwise stated), $200 \mathrm{mM}$ $\mathrm{NaCl}, 50 \mu \mathrm{g} / \mathrm{ml}$ viral RNA and $1 / 10$ volume of poly(A) polymerase. Incubation was terminated by the addition of SDS to $0.2 \%$ and EDTA to $20 \mathrm{mM}$. The extent of adenylation was determined by TCA precipitation of a $5 \mu 1$ aliquot of the incubation. The remainder was extracted with phenol and chloroform as described above and the final aqueous phase precipitated by the addition of an equal volume of $4 \mathrm{M} \mathrm{NH}_{4} \mathrm{Ac}$ and then 2.5 volumes of ethanol.

Synthesis of CDNA

DNA complementary to the polyadenylated viral RNA was synthesised in a mixture containing $50 \mathrm{mM}$ Tris- $\mathrm{HCl} \mathrm{pH} 8.3,0.2 \mathrm{mM}$ dGTP, $0.2 \mathrm{mM}$ dATP, $0.2 \mathrm{mM}$ TTP, $50 \mu \mathrm{M} \mathrm{dCTP}\left({ }^{32} \mathrm{P}\right.$ or ${ }^{3} \mathrm{H}$ as indicated $), 5 \mathrm{mM}$ DTT, $0.01 \%$ Triton $\mathrm{X}-100,50$ $\mu \mathrm{g} / \mathrm{ml}$ actinomycin $\mathrm{D}, 40 \mathrm{mM} \mathrm{KCl}, 10$ units/ml rat liver ribonuclease inhibitor, $5 \mu \mathrm{g} / \mathrm{ml}$ oligo(dT) $12-18,20 \mu \mathrm{g} / \mathrm{ml}$ adenylated RNA and 60 units/ml reverse transcriptase. After incubation at $37^{\circ} \mathrm{C}$ for $90 \mathrm{~min}$, the mixture was made $0.2 \%$ with SDS, $20 \mathrm{mM}$ with EDTA and a $10 \mu 1$ aliquot removed for TCA precipitation. To the remainder was added an equal volume of $4 \mathrm{M} \mathrm{NH}_{4} \mathrm{Ac}$ and the cDNA precipitated by the addition of 2.5 volumes of ethanol. cDNA was recovered by centrifugation, dissolved in $100 \mu 1 \mathrm{H}_{2} \mathrm{O}$ and then made to $100 \mathrm{mM}$ with $\mathrm{NaOH}$. After incubation at $70^{\circ} \mathrm{C}$ for $20 \mathrm{~min}$, the sample was neutralised with acetic acid and chromatographed on a $50 \times 0.7 \mathrm{~cm}$ column of Sephadex G-150 equilibrated in $50 \mathrm{mM} \mathrm{NaCl} / 0.1 \%$ SDS. DNA eluting in the void volume was pooled and concentrated by ethanol precipitation. 
Synthesis of double-stranded cDNA

Double-stranded CDNA was synthesised from ${ }^{3} \mathrm{H}-1$ abelled single-stranded cDNA in an incubation containing $50 \mathrm{mM}$ Tris $\mathrm{pH} 8.3,20 \mathrm{mM} \mathrm{DTT}, 10 \mathrm{mM} \mathrm{MgCl} 2$, $0.4 \mathrm{mM}$ dGTP, $0.4 \mathrm{mM}$ dATP, $0.4 \mathrm{mM}$ TTP, $0.1 \mathrm{mM}$ dCTP (the concentration of radioactivity is given in the Figure Legends), 2.5-10 $\mu \mathrm{g} / \mathrm{ml}$ cDNA and 400 units/ml reverse transcriptase. Incubation was at $45^{\circ} \mathrm{C}$ for the indicated periods. The reaction mixture was then made $20 \mathrm{mM}$ with EDTA, $0.2 \%$ with SDS, extracted with phenol and chloroform, and placed on a Sephadex G-50 column $(20 \times 0.7 \mathrm{~cm})$ equilibrated in $50 \mathrm{mM} \mathrm{NaCl}$ and $0.1 \%$ SDS. The excluded fractions were pooled.

Gel electrophoresis

RNA samples were electrophoresed on $3.7 \%$ or $4 \%$ acrylamide disc gels in 98\% formamide prepared as described (12). After electrophoresis, gels were soaked for 2-3 hr in $30 \%$ glycerol/5\% acetic acid and then scanned in a JoyceLoebl u.v. gel scanner.

Samples of viral RNA dissolved in $7 \mathrm{M}$ urea were also analysed on $3 \%$ acrylamide gels containing $7 \mathrm{M}$ urea. The electrophoretic procedure was as described (2), except that both the gels and upper reservoir buffer contained $7 \mathrm{M}$ urea. The RNA bands were stained for $1 \mathrm{hr}$ in $0.02 \%$ methylene blue in citrate-EDTA and then gel destained in water.

Native DNA samples were examined on $1.4 \%$ agarose ge1s in Tris-acetateEDTA buffer (13). For single-stranded DNA molecules, a $1.4 \%$ agarose slab ge1 $(20 \times 15 \times 0.5 \mathrm{~cm})$ in $30 \mathrm{mM} \mathrm{NaOH}, 2 \mathrm{mM}$ EDTA was used (14). These agarose gels were dried (15) before autoradiography using Kodak XH-1 film and intensifying screens.

S1 nuclease treatment

The products of the reverse transcriptase reactions, reannealed doublestranded CDNA and RNA/CDNA hybrids were treated with S1 nuclease purified from $\alpha$-amylase (11). The reaction mixtures (100-200 $\mu 1)$ contained $150 \mathrm{mM}$ $\mathrm{NaC1}, 25 \mathrm{mM}$ sodium acetate $\mathrm{pH} \mathrm{4.6,1} \mathrm{mM} \mathrm{ZnSO}{ }_{4}$, DNA and 2.5-5 units of $\mathrm{S} 1$ nuclease and incubation was at $37^{\circ} \mathrm{C}$ for $30 \mathrm{~min}$. Percent hybridisation was determined by TCA precipitation while samples for electrophoresis were phenol extracted and ethanol precipitated.

Hybridisation

Samples of viral RNA and cDNA for hybridisation or double-stranded cDNA for reassociation were dissolved in 10-20 $\mu 1$ of $300 \mathrm{mM} \mathrm{NaCl}, 10 \mathrm{mM}$ Hepes $\mathrm{pH}$ $6.8,0.5 \mathrm{mM}$ EDTA, $0.1 \%$ SDS, sealed in siliconised glass capillaries, denatured for $3 \mathrm{~min}$ at $100^{\circ} \mathrm{C}$ and incubated at $68^{\circ} \mathrm{C}$ for the indicated times. 
Double-strand formation was assayed using S1-nuclease as described above. Preparation of $32 \mathrm{P}-1$ abelled RNA fragments

Viral RNA was fractionated on $3 \%$ polyacrylamide gels in $7 \mathrm{M}$ urea as described above, the bands excised and RNA eluted as described (16). The RNA was fragmented by digestion in $0.1 \mathrm{M}$ sodium hydroxide for $1 \mathrm{hr}$ in ice then neutralised and precipitated with ethanol. The fragments were terminally labelled by incubation at $37^{\circ} \mathrm{C}$ for $1 \mathrm{hr}$ in a mixture $(10 \mu 1)$ containing $10 \mu \mathrm{Ci} \mathrm{r}^{32} \mathrm{P}-$ polynucleotide kinase. After incubation, the labelled fragments were chromatographed on a $0.7 \times 20 \mathrm{~cm}$ column of Sephadex G-50 (M).

\section{Nitrocellulose filter methodology}

cDNA was electrophoresed on alkaline agarose gels as described above and then transferred to nitrocellulose sheets as described (17). Filters were hybridised to labelled probes in $50 \%$ formamide, $5 \times$ SSC at $37^{\circ} \mathrm{C}$ for $16 \mathrm{hr}$.

\section{$\underline{\text { RESULTS }}$}

\section{Analysis of the virus genome}

The eight single-stranded RNA molecules comprising the genome of Influenza A Viruses are readily resolved on polyacrylamide or agarose gels in the presence of urea. The chain lengths of the RNA species have been estimated, in a number of cases, using ribosomal RNAs as standards, to range from $10^{5}$ to $1.2 \times 10^{6}$ daltons (see for example 18,19 ).

We have analysed the virion RNA from both Fowl Plague and A/Victoria Virus on two denaturing gel systems: $7 \mathrm{M}$ urea, $\mathrm{pH} 3.5$ and $98 \%$ formamide. Fig. 1a compares the mobility of A/Victoria RNA with that of E.coli rRNA and 18S chick rRNA on acrylamide gels in the presence of urea. The viral RNA separates into eight species, although Band 1 tended to be more diffuse than the others. By comparing the mobilities of the RNA species with the mobilities of the ribosomal RNAs, we have estimated their chain lengths; these are shown in Table 1 and, generally, agree with published data $(18,19)$.

Electrophoresis of virion RNA on formamide disc gels is shown in Fig. 1b. Although this system failed to resolve genes $1-3$, it is clear that relative to E.coli rRNA, the six large species migrate more rapidly. This is reflected in the lower chain lengths estimated from these formamide gels (Table 1). This difference in migration on the two gel systems is discussed below. Characterisation of the polyadenylation reaction

The poly(A) polymerase showed an absolute requirement for either $\mathrm{Mg}^{++}$ or $\mathrm{Mn}^{++}$ions. Maximal activity was found with a combination of $10 \mathrm{mM} \mathrm{MgCl} 2$ 

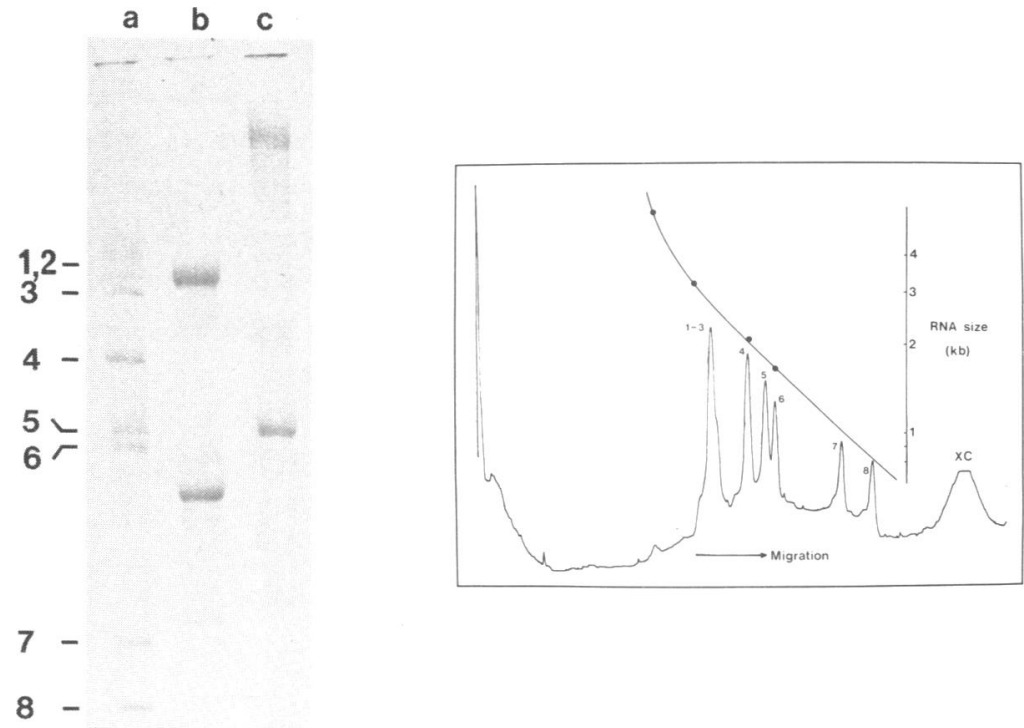

$8-$

Figure 1. Separation of VRNA segments of A/Victoria by polyacrylamide gel electrophoresis.

a) RNA was separated on a $3.0 \%$ polyacrylamide slab gel in $7 \mathrm{M}$ urea (20 $\mathrm{cm})$ at $80 \mathrm{~V}$ for $16 \mathrm{hr}$ and visualised by staining with methylene blue. $a=\mathrm{A} / \mathrm{Vic}-$ toria vRNA, $b=E . c o l i$ 16S and $23 \mathrm{~S}$ ribosomal $\mathrm{RNA}, \mathrm{c}=$ hen oviduct $18 \mathrm{~S}$ and $28 \mathrm{~S}$ ribosomal RNA. The viral RNA genes are numbered 1-8.

b) RNA samples in $98 \%$ formamide were heated at $680^{\circ} \mathrm{C}$ for 4 min before electrophoresis on a $3.7 \%$ polyacrylamide disc gel $(10 \mathrm{~cm})$ in $98 \%$ formamide at $150 \mathrm{~V}$ for $6 \mathrm{hr}$. Gels were scanned at $265 \mathrm{~nm}$. The positions of E.coli $16 \mathrm{~S}$ and 23S ribosomal RNA and of oviduct $18 \mathrm{~S}$ and $28 \mathrm{~S}$ ribosomal RNA on parallel gels are shown.

and $1 \mathrm{mM} \mathrm{MnC1}{ }_{2}$. In agreement with the results of Sippel (10), the enzyme also had a specific requirement for high $\mathrm{NaCl}$ concentrations for maximal activity; this was obtained at $260 \mathrm{mM} \mathrm{NaCl}$ with a sharp decrease in activity at higher ionic strength (data not shown).

For the poly(A) polymerase to be useful in further studies involving transcription, it was important that the enzyme was free of nucleases. Consequently, the poly(A) polymerase was assayed for ribonuclease contamination using E.coli rRNA as a substrate by examining its migration on denaturing formamide gels after incubation. A 5 min incubation at $37^{\circ} \mathrm{C}$ produced little degradation of the RNA relative to the control incubated in the absence of enzyme (data not shown but see Fig. 2). 
Table 1

RNAs of FPV and A/Victoria Virus

\begin{tabular}{|c|c|c|c|c|}
\hline \multirow[b]{2}{*}{ Gene } & \multicolumn{2}{|c|}{ FPV (nucleotides) } & \multicolumn{2}{|c|}{ A/Victoria (nucleotides) } \\
\hline & 7 M Urea ${ }^{*}$ & Formamide & 7 M Urea & Formamide \\
\hline 1 & 3500 & {[} & $(3700)$ & {$[2700$} \\
\hline 2 & 3000 & $2660-2720$ & 3400 & \\
\hline 3 & 2950 & L & 3200 & 2610 \\
\hline 4 & 2450 & 2060 & 2600 & 2060 \\
\hline 5 & 2000 & 1800 & 2100 & 1790 \\
\hline 6 & 1720 & 1560 & 2000 & 1680 \\
\hline 7 & 1080 & 980 & 1080 & 1050 \\
\hline 8 & 870 & 830 & 880 & 850 \\
\hline
\end{tabular}

* Data taken from (19)

Viral RNA (5-10 $\mu \mathrm{g})$ was electrophoresed either on slab gels containing $7 \mathrm{M}$ urea in citrate/EDTA buffer and then stained with methylene blue (Fig. la) or on disc gels containing $98 \%$ formamide and then scanned at $265 \mathrm{~nm}$ (Fig.

1b). RNA chain lengths were deduced from plots of migration vs log (chain length) using E.coli rRNA (1680 and 3240 nucleotides) and chick 18S rRNA (2100) as standards.

A11 eight viral genes are polyadenylated

Although the poly(A) polymerase preparation was completely primer dependent, it was important to demonstrate that all eight genome segments were capable of being polyadenylated and to show a physical attachment of the poly(A) region to them. A standard assay mixture containing $10 \mu \mathrm{g}$ FPV-RNA was incubated at $37^{\circ} \mathrm{C}$ for $3 \mathrm{~min}$ and then analysed on $4 \%$ acrylamide gels in 98\% formamide. Fig. 2 shows that after this short incubation period, the incorporated radioactivity coincided exactly with the optical density profile obtained by scanning the gel. We calculated that in this experiment, an average of 40 adenylate residues was added per molecule. These poly(A) tails are evidently not long enough to produce the drastic change in migration and sedimentation properties observed for MS-2 RNA (20).

To achieve maximal transcription of the polyadenylated RNA using oligo(dT) ${ }_{12-18}$ as a primer, it is essential that (a) the majority of the RNA segments are adenylated and (b) the length of the poly(A) tail is enough to 


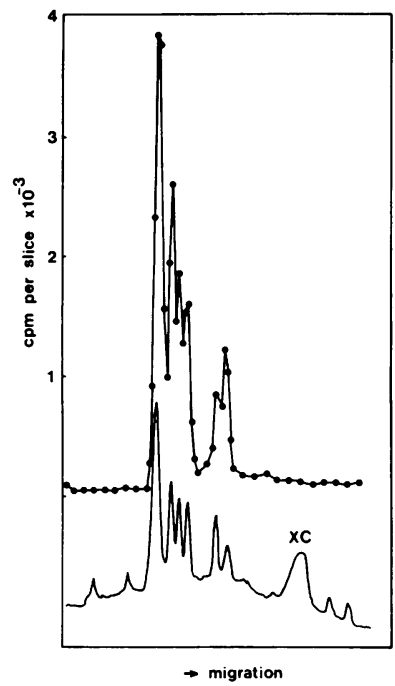

Figure 2. Electrophoresis of FPV-RNA after polyadenylation. $10 \mu \mathrm{g}$ FPV-RNA was adenylated at $37^{\circ} \mathrm{C}$ for $3 \mathrm{~min}$ in the presence of $20 \mu \mathrm{Ci} / \mathrm{ml} 3 \mathrm{H}-\mathrm{ATP}$. After phenol extraction and ethanol precipitation, vRNA was dissolved in $98 \%$ formamide, heated at $68^{\circ} \mathrm{C}$ for $2 \mathrm{~min}$. After rapid cooling, the RNA was electrophoresed on a $4 \%$ polyacrylamide gel in $98 \%$ formamide. The ge 1 was scanned at $265 \mathrm{~nm}$ with a Joyce-Loeb1 ultraviolet scanner (-) and then cut into $100 \times 1 \mathrm{~mm}$ slices. Slices were incubated at $37^{\circ} \mathrm{C}$ overnight with $0.5 \mathrm{ml}$ of $95 \%$ NCS and then counted for radioactivity $(\bullet)$.

promote transcription. Thus we incubated $2.5 \mathrm{\mu g}$ aliquots of FPV-RNA with increasing quantities of poly(A) polymerase at $37^{\circ} \mathrm{C}$ for $2 \frac{1}{2} \mathrm{~min}$. The polyadenylated RNA was recovered, added to a transcription mixture and incubated with oligo(dT) and reverse transcriptase at $37^{\circ} \mathrm{C}$ for $90 \mathrm{~min}$. The results of this experiment are shown in Figs. $3 \mathrm{a}$ and $3 \mathrm{~b}$. The extent of adenylation was proportional to the enzyme concentration over the range examined (up to $50 \mathrm{~A}$ 's per molecule). Transcription, however, began to plateau after approximately $30 \mathrm{~A}^{\prime} \mathrm{s}$ per molecule had been added ${ }^{*}$, indicating that a poly(A) tail of sufficient length for efficient priming had been produced.

The results of Fig. 3 apply to the bulk of the RNA and no conclusion can be drawn as to the relative efficiency of transcription of individual genes. To examine this, we adenylated the A/Victoria RNA for 1 or 2 min (the latter time was sufficient for maximal transcription), transcribed it and electrophoresed the DNA products on a denaturing gel (Fig. 4). Although total incorporation after 1 min was only $50 \%$ of that after $2 \mathrm{~min}$, it is clear that transcription was biased in favour of Band C (gene 4) at the early time. After 2 min adenylation, however, the DNA bands were of more regular intensity.

* The number of adenylate residues added per molecule was calculated as the

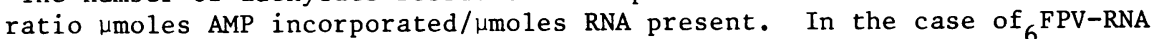
which has RNA species varying in molecular weight of $0.3-1.2 \times 10^{6}$ daltons, an average molecular weight of $0.7 \times 10^{6}$ daltons was used in the calculation. 

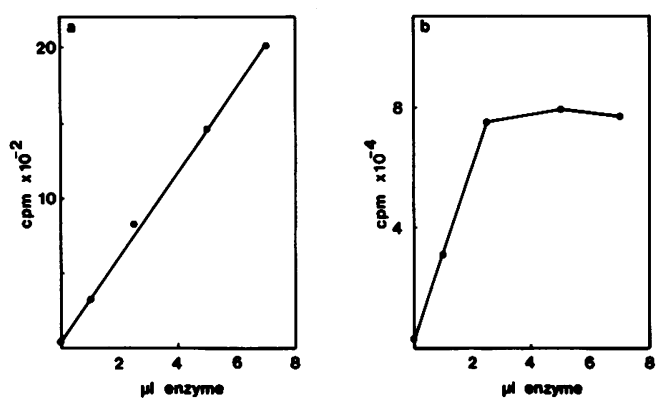

Figure 3. Effect of poly(A) polymerase concentration on adenylation and reverse transcription of FPV-RNA. Five standard adenylation reactions, 50 $\mu 1$ each and containing $1 \mu \mathrm{Ci} 3 \mathrm{H}-\mathrm{ATP}$, were incubated at $37^{\circ} \mathrm{C}$ for $2 \frac{1}{2}$ min with increasing quantities of poly(A) polymerase. Incubations were terminated by the addition of SDS to $0.2 \%$ and EDTA to $20 \mathrm{mM}$ and $5 \mu 1$ aliquots were removed for TCA precipitation (a). The remainder of each incubation was extracted with phenol and chloroform, precipitated with ethanol and then added to a $100 \mu 1$ reverse transcription incubation containing $32 \mathrm{P}-\mathrm{dCTP}(30 \mu \mathrm{Ci} / \mathrm{ml})$ as the radioactive deoxynucleotide triphosphate. After $90 \mathrm{~min}$ at $37^{\circ} \mathrm{C}, 10 \mu 1$ aliquots were removed from each reaction for TCA precipitation (b).

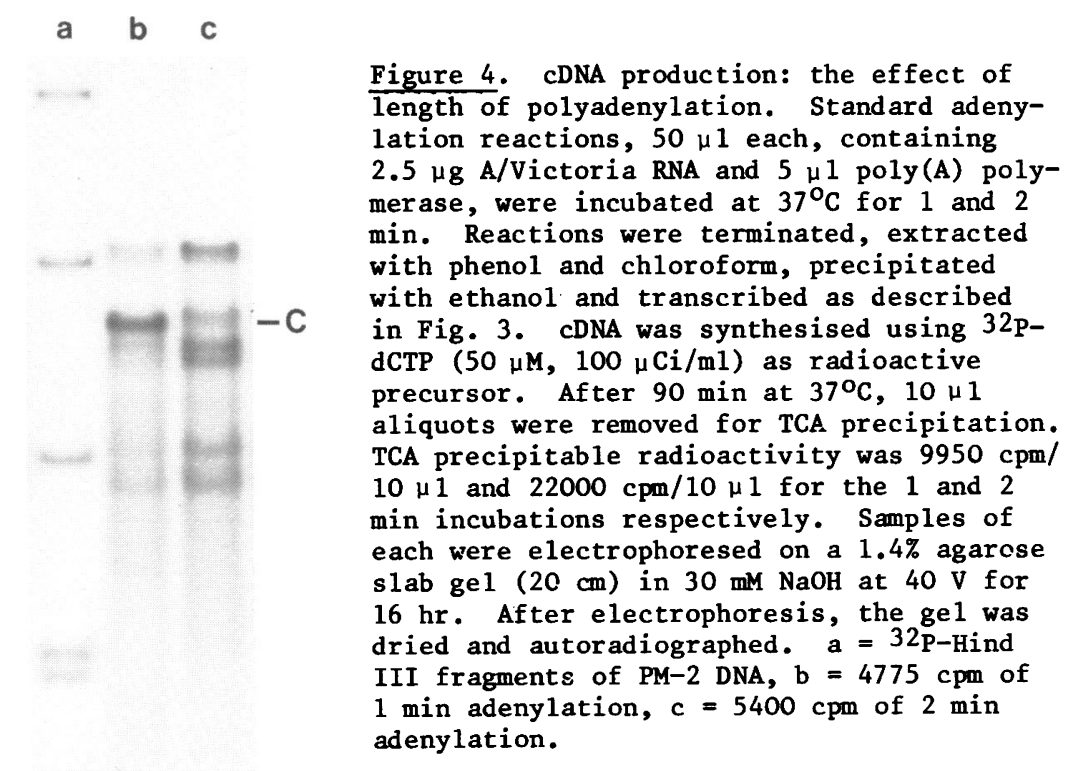


Analysis of the transcription products

cDNA was recovered after $\mathrm{NaOH}$ digestion as described in the Methods section. This material was $>96 \%$ sensitive to S1-nuclease, indicating that it indeed is single-stranded, and became $>90 \%$ resistant to S1-nuclease after annealing with an excess of viral RNA (Table 2). We examined the lengths of the cDNA transcripts by electrophoresis on $1.4 \%$ agarose gels run in $30 \mathrm{mM}$ $\mathrm{NaOH}$ to ensure completely denaturing conditions. Fig. 5 shows an autoradiograph of cDNA synthesised from polyadenylated FPV and A/Victoria RNA and the Hind III fragments of bacteriophage PM-2 DNA. The sizes of these latter fragments were determined on both agarose and acrylamide gels using the Hpa I and Hae III fragments of $\emptyset \times 174$ as references and are given in the legend to Table 3 .

Both cDNA preparations resolved into 7 bands, A-G, the lengths of which are given in Table 3. On the basis of their estimated sizes and relative mobilities, we have tentatively assigned them as follows: Band $A$ is comprised mainly of genes 1 and 2, Band B contains mainly gene 3 transcripts, Band $\mathrm{C}$ is equivalent to gene 4 , Band $D$ to gene 5 , Band $E$ to gene 6 , Band $F$ to gene 7 and Band $G$ to gene 8 . We provide further evidence for these assignments below. Assuming the cDNA bands are equivalent to the RNA segments of the virus, we calculate a genome size of 14,600 nucleotides $\left(4.8 \times 10^{6}\right.$ daltons) for A/Victoria and 14,820 nucleotides $\left(4.9 \times 10^{6}\right.$ daltons) for Fowl Plague Virus.

\section{The cDNA bands represent copies of individual genes}

Although we have shown that all the viral RNA species are polyadenylated and that the pattern of cDNA produced reflects that of the starting RNA, we cannot exclude the possibility that the smaller cDNA bands are produced by

$\underline{\text { Table } 2}$

Characterisation of FPV-cDNA

\begin{tabular}{|l|c|}
\hline \multicolumn{1}{|c|}{ Sample } & $\%$ S1 resistant \\
1. FPV-cDNA & 2.6 \\
2. denatured cDNA & 1.4 \\
3. denatured cDNA, hybridised & 7.4 \\
4. cDNA + 1 Hg FPV-RNA, denatured \\
\begin{tabular}{l} 
and hybridised \\
\hline
\end{tabular}
\end{tabular}




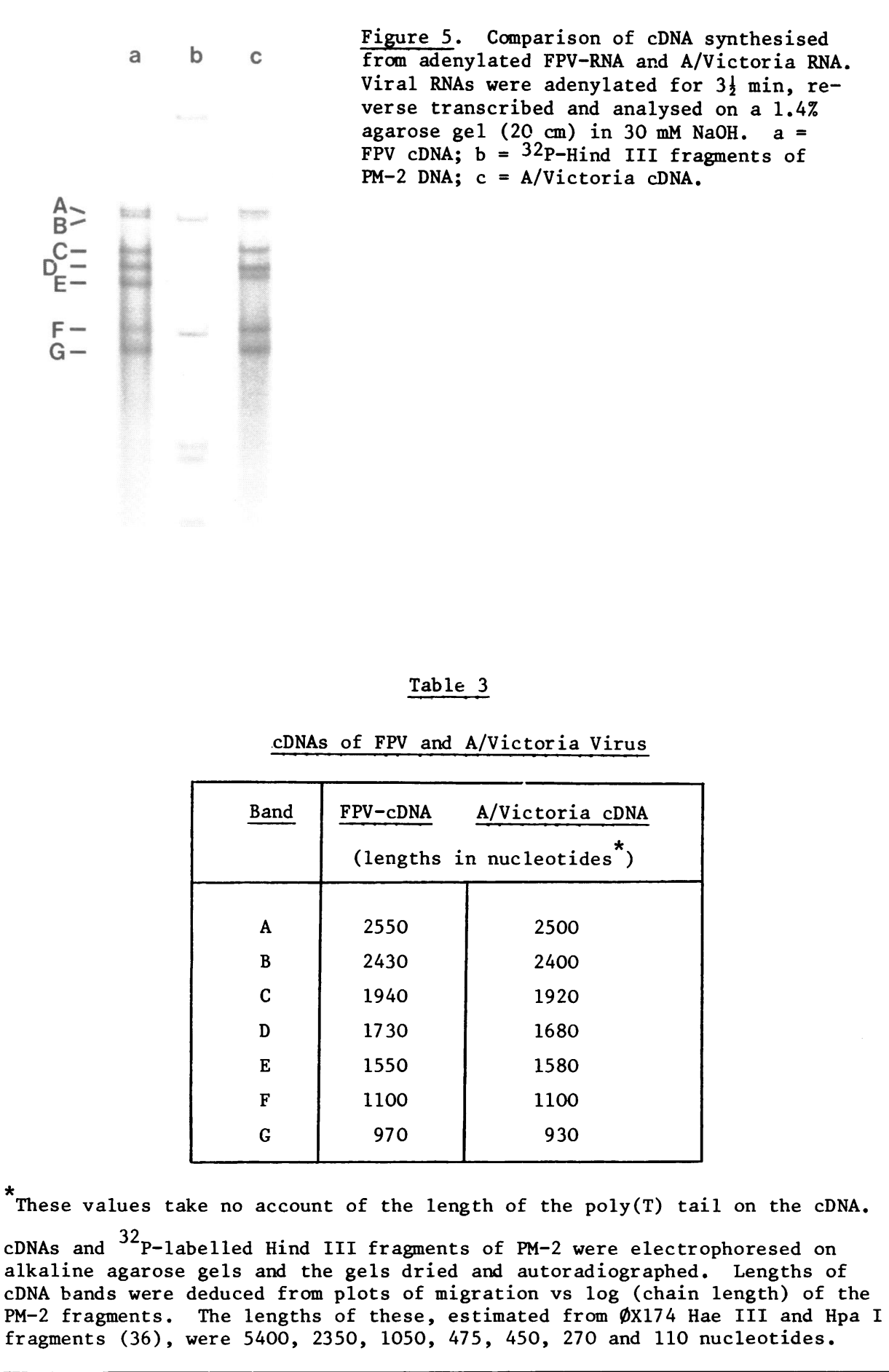

Figure 5. Comparison of cDNA synthesised from adenylated FPV-RNA and A/Victoria RNA. Viral RNAs were adenylated for $3 \frac{1}{2} \mathrm{~min}$, reverse transcribed and analysed on a $1.4 \%$ agarose ge $1(20 \mathrm{~cm})$ in $30 \mathrm{mM} \mathrm{NaOH} . \quad a=$ FPV cDNA; $b=32 \mathrm{P}$-Hind III fragments of PM-2 DNA; $c=A /$ Victoria cDNA.

Table 3

cDNAs of FPV and A/Victoria Virus

\begin{tabular}{|c|c|c|}
\hline Band & FPV-cDNA & \multicolumn{2}{|c|}{ A/Victoria cDNA } \\
& (lengths in nucleotides ${ }^{*}$ ) \\
\hline A & 2550 & 2500 \\
B & 2430 & 2400 \\
C & 1940 & 1920 \\
D & 1730 & 1680 \\
E & 1550 & 1580 \\
F & 1100 & 1100 \\
G & 970 & 930 \\
\hline
\end{tabular}

*These values take no account of the length of the poly(T) tail on the cDNA. cDNAs and ${ }^{32} \mathrm{P}-1$ abelled Hind III fragments of PM-2 were electrophoresed on alkaline agarose gels and the gels dried and autoradiographed. Lengths of cDNA bands were deduced from plots of migration vs log (chain length) of the PM-2 fragments. The lengths of these, estimated from $\emptyset \times 174$ Hae III and Hpa I 
"strong stop" signals in some of the larger RNA species. To demonstrate a relationship between individual RNA and DNA bands, we have fractionated the genome of A/Victoria, isolated the RNA bands corresponding to genes 4 and 7 and labelled them using polynucleotide kinase and $\gamma-{ }^{32}$ P-ATP. These labelled fragments were then used as probes and hybridised to a "Southern-blot" of cold A/Victoria cDNA. The results, shown in Figure 6, clearly demonstrate that the gene 4 probe hybridises specifically to Band $C$ while the gene 7 probe hybridises to Band F. We conclude, therefore, that the cDNA bands do indeed represent individual genes. Whether they are complete or lack the sequence corresponding to the $5^{\prime}$-terminal end of the virion RNA as the mRNA does (21) remains to be determined.

\section{Hybridisation studies}

We next attempted to characterise the cDNA to establish whether it represented a true complementary copy of the viral RNA; although the cDNA bands

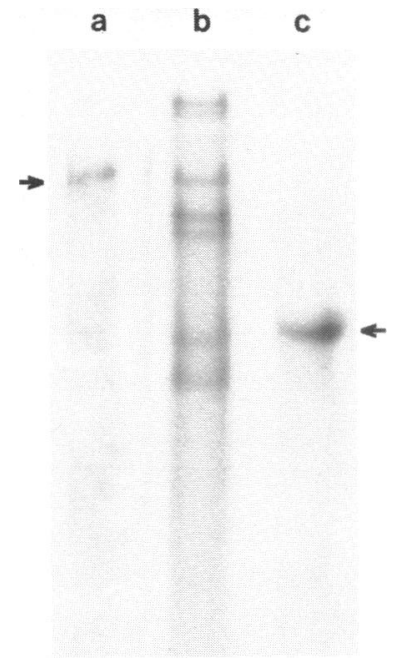

Figure 6. Hybridisation of fractionated virion RNA to cDNA on Millipore filters. A/Victoria RNA was polyadenylated, $3 \mathrm{H}-$ and $32 \mathrm{P}-\mathrm{cDNA}$ prepared and electrophoresed on a $1.4 \%$ agarose gel in $30 \mathrm{mM} \mathrm{NaOH}$. After electrophoresis, the gel was neutralised and the cDNA transferred to a nitrocellulose filter. a = $20 \mathrm{ng} 3 \mathrm{H}-\mathrm{cDNA} ; \mathrm{b}=32 \mathrm{P}-\mathrm{cDNA}, 10^{3} \mathrm{cpm} ; \mathrm{c}=20 \mathrm{ng} 3 \mathrm{H}-\mathrm{cDNA}$. The filters were cut into strips and hybridised to $32 \mathrm{P}$-labelled RNA probes prepared from genes 4 and 7 . The strips were wet with a minimum volume of hybridisation solution ( $50 \%$ formamide, $5 \times$ SSC and $105 \mathrm{cpm} / \mathrm{ml}$ of $32 \mathrm{P}-\mathrm{RNA}$ ), covered with liquid paraffin and left at $37^{\circ} \mathrm{C}$ overnight. Following hybridisation, the filter strips were washed four times with $50 \%$ formamide, $5 \times \mathrm{SSC}$, once with $2 \times \mathrm{SSC}$, once with $2 \times$ SSC containing $10 \mu \mathrm{g} / \mathrm{m} 1$ pancreatic RNAase and finally twice with $2 \times$ SSC. Dried strips were then autoradiographed. $a=$ RNA probe from gene $4 ; c=$ RNA probe from gene 7 . 
were large enough to contain near complete transcripts of Influenza RNA, its length might have been partly the result of anomalous synthesis of a homopolymer $(22,23)$ or "slippage" during transcription so that part of the mRNA was transcribed more than once..

Figure 7 shows the melting profile of vRNA/cDNA hybrids and the kinetics of hybridisation of CDNA to an excess of vRNA. The sharp melting transition at $88^{\circ} \mathrm{C}$ and the lack of significant melting below $80^{\circ} \mathrm{C}$ indicates that very little base pair mis-matching occurred. Similarly, the cDNA hybridisation reaction occurred within a 100-fold range of vRNA Cot values with a $\operatorname{Cot} \frac{1}{2}$ of $4.8 \times 10^{-3} \mathrm{~mol}$. sec. $1 \mathrm{it}^{-1}$ (at $0.3 \mathrm{M} \mathrm{NaCl}$ ) and obtained a value of greater than $90 \%$ hybridisation.

\section{Synthesis of double-stranded DNA}

To produce synthetic genes from the single-stranded cDNA, we utilised the self-priming ability of the cDNA (24). Total ${ }^{3} \mathrm{H}$-cDNA was purified free of vRNA as described and used as template in a second reverse transcriptase reaction, in the presence of ${ }^{32} \mathrm{P}-\mathrm{dCTP}$ but without actinomycin $\mathrm{D}$. As seen in Fig. 8, incorporation of radioactivity into acid insoluble material proceeded for 3-4 hr. During this time, DNA synthesis amounted to $40-50 \%$ of the input cDNA. In agreement with this figure, $40-50 \%$ of the ${ }^{3} \mathrm{H}$ counts were rendered S1-resistant while $100 \%$ of the ${ }^{32} \mathrm{P}$ counts were sl-resistant.

As shown for globin (24) and for ovalbumin (25), the second DNA strand

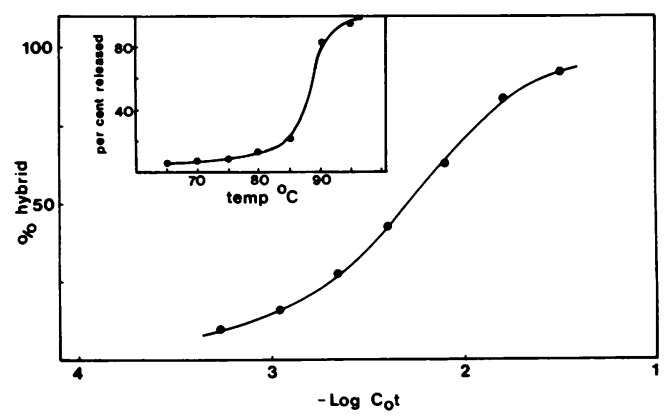

Figure 7. Hybridisation kinetics of FPV cDNA to FPV RNA. ${ }^{32}$ P-labelled FPV CDNA $(2.5 \mathrm{ng}, 4000 \mathrm{cpm})$ was hybridised at $68^{\circ} \mathrm{C}$ for $2 \mathrm{~min}$ to $2 \mathrm{hr}$ with an excess of vRNA ( $30 \mathrm{ng}$ ) in a final volume of $20 \mu 1$. The percentage of cDNA hybridised was determined using $\mathrm{S} 1$ nuclease as described in Materials and Methods. The insert shows the melting profile of the cDNA/RNA hybrid. The hybrid was absorbed to a $0.5 \mathrm{ml}$ hydroxyapatite column at $65^{\circ} \mathrm{C}$ in $0.14 \mathrm{M} \mathrm{Na}-$ phosphate $\mathrm{pH} 7$. The temperature of the column was raised as indicated and single-stranded material eluted with $2.5 \mathrm{ml} 0.14 \mathrm{M}$ phosphate $\mathrm{pH} 7$. The eluted material was TCA precipitated and counted. 


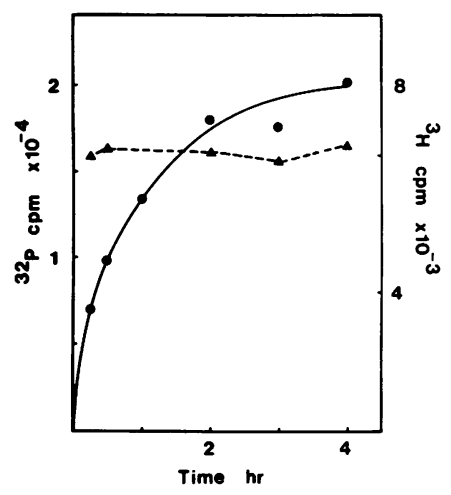

Figure 8. Kinetics of second-strand synthesis. $3 \mathrm{H}$-labelled FPV cDNA $(5 \mathrm{\mu g} /$ $\mathrm{m} 1)$ was incubated at $45^{\circ} \mathrm{C}$ with reverse transcriptase (200 units/ml) as described in Materials and Methods. $5 \mu 1$ aliquots were removed at the indicated times and TCA precipitable radioactivity estimated. $\longrightarrow, 32 \mathrm{P} \mathrm{cpm} ;\left\llcorner---, 3_{\mathrm{H}} \mathrm{cpm}\right.$.

is covalently bound to the cDNA by a "hairpin" structure that is susceptible to S1-nuclease. Such a structure implies that after denaturation, the molecules should "snap-back" immediately; after S1-nuclease treatment, however, reannealing of the strands should follow normal kinetics. The results of such an experiment are shown in Fig. 9. Double-stranded DNA, labelled with ${ }^{32} \mathrm{P}$ in the second strand and either treated or non-treated with s1-nuclease, was denatured $\left(100^{\circ} \mathrm{C}\right.$ for 3 mins) and then reannealed at $68^{\circ} \mathrm{C}$ for the indicated periods. The majority of the DNA with no prior S1-treatment was in a double-stranded form, even at the very early times (estimated cot of less than $10^{-6}$ mol. sec. 1 it $^{-1}$ ), while that with S1-treatment reannealed with a $\cot \frac{1}{2}$ of approximately $10^{-3} \mathrm{~mol}$. sec. $1 \mathrm{it}^{-1}$.

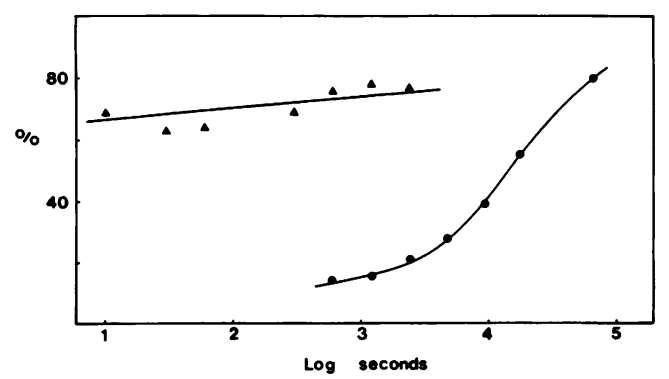

Figure 9. "Hairpin" structures are cut by S1-nuclease to produce "open" genes. Double-stranded FPV DNA, labelled with 32P in the second strand, was produced as described in Materials and Methods. A portion was treated with S1-nuclease and then reannealed after denaturation while a second sample was denatured and reannealed directly. ( $\longrightarrow)$, reannealing after Sl-nuclease digestion; ( $\backsim$ ), reannealing without S1-nuclease treatment. Each incubation contained approximately $0.5 \mathrm{ng} \mathrm{DNA} / 10 \mu 1$. 
Thus the combination of reverse transcriptase and S1-nuclease is sufficient to produce synthetic viral genes. However, when double-stranded DNA was synthesised from unfractionated cDNA, the product, although containing some DNA bands equivalent to complete gene copies, consisted mainly of smaller molecules (results not shown). In an attempt to increase the yield of long gene copies, the single-stranded cDNA was fractionated prior to the second reverse transcriptase reaction. Thus, cDNA from A/Victoria vRNA was fractionated on an $\mathrm{NaOH}$ gel as in Figs. 4 and 5 and the bands corresponding to genes 4, 5, 6, 7 and 8 eluted from gel slices. Following reverse transcription and S1-nuclease digestion, samples were analysed on a neutral agarose gel. The results, shown in Fig. 10, indicate that the products in each case consist mainly of double-stranded molecules approximately equal in size to the cDNA molecules used in the incubation.

\section{DISCUSSION}

The Influenza Virus particle contains on its surface two immunologically and morphologically separate antigens, the hemagglutinin and the neuraminidase. It is the antigenic variability of these proteins that accounts for the

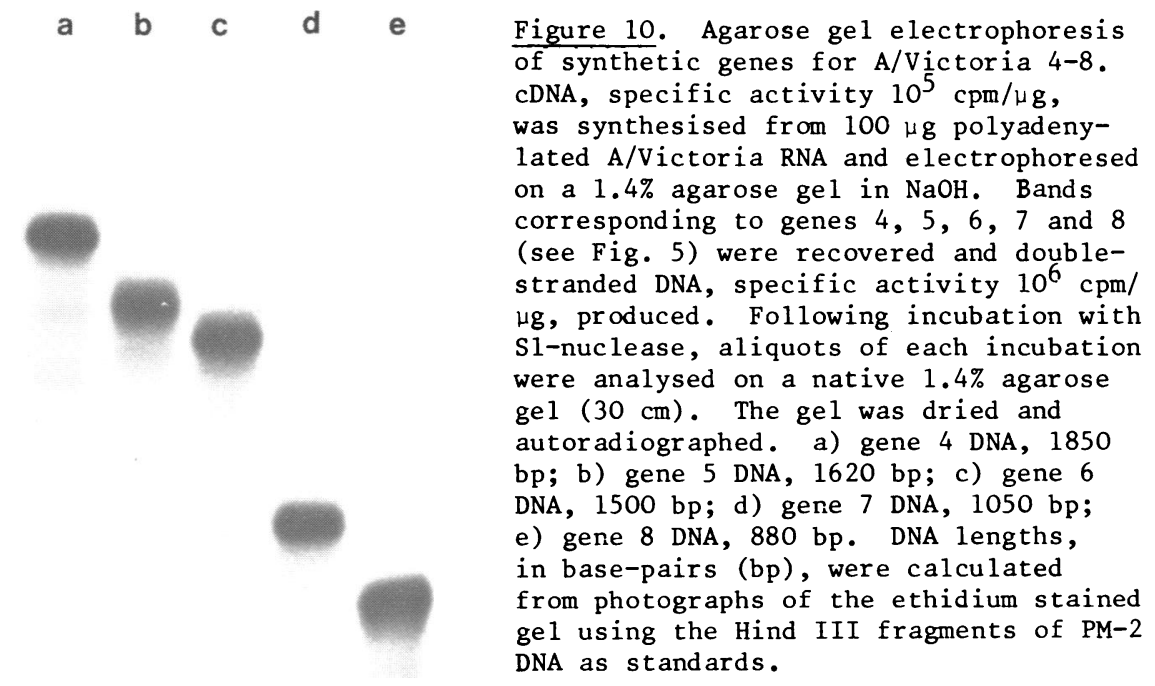


success of Influenza A Virus as a human pathogen. Two types of antigenic change are known to occur; the first, termed antigenic "shift", arises when viruses with major antigenic changes emerge, and is associated with pandemics. In between pandemics, frequent minor but progressive changes occur in the surface antigens, termed antigenic "drift" - these comprise the second type (for a review see (26)). The ability to produce synthetic DNA genes from mRNA with reverse transcriptase and the rapid development of genetic engineering and DNA sequencing methods now allow us to determine how the primary structure of the surface antigens changes in human pandemic Influenza Virus strains and to examine the regulatcry sequences in the relevant genes. Our approach to transcribing the viral genome was to adenylate the RNA with poly(A) polymerase and then use oligo(dT) as primer. The enzyme from E.coli has been described $(10,20,23)$ and, as shown in Fig. 2, can be purified free of ribonuclease. Optimal adenylation occurred very quick1y and, assuming that all RNA molecules are adenylated, maximal transcription occurred when $30 \mathrm{~A}^{\prime}$ 's per molecule were added (Fig. 3). Interestingly, from Fig. 4 , it appears that gene 4 of A/Victoria is adenyated more rapidly than the others, possibly reflecting a more open structure near the $3^{\prime}$ end of the molecule.

The differences observed in the sizes of viral RNA in urea gels (Table 1) and the cDNA bands (Table 3) prompted us to look at the RNA on other denaturing systems. The determination of RNA chain length by gel electrophoresis is fraught with difficulties stemming from the fact that RNA molecules generally do not have hydrodynamically equivalent conformations in aqueous solution. Several procedures have been developed to ensure denaturation; among these are buffers containing $6 \mathrm{M}$ urea at $\mathrm{pH} 3.5,5 \mathrm{mM}$ methy 1 mercury or 98\% formamide. Lehrach et al. (27) have recently examined a number of such systems and observed that, although urea gels at acid $\mathrm{pH}$ gave geod separation of RNA molecules, they were unreliable for molecular weight determinations because differences in structure and protonation resulted in anomalous migration. Moreover, the work of Boedtker (28) and Rejinders et al. (29) suggests that $6 \mathrm{M}$ urea at neutral pH, the method generally used in determining the size of Influenza Viral RNAs, does not fully denature most RNA molecules at room temperature. Electrophoresis in $98 \%$ formamide, especially after the samples are heated at $68^{\circ} \mathrm{C}$ for $4 \mathrm{~min}$ in formamide, should ensure more complete denaturation. Under these conditions, the sizes of the viral RNA (Table 1) and the cDNA products are in better agreement, leading to the conclusion that the cDNA bands probably represent complete or near-complete copies of 
the viral genome and that the sizes of the Influenza genes may have been over-estimated in previous work. Indeed, Desselberger and Palese (30) have recently published revised molecular weights for Influenza $A$ and $B$ Viruses based on denaturation in $1 \mathrm{M}$ glyoxal at $50^{\circ} \mathrm{C}$. Their findings agree well with ours; thus the genome size is estimated as $4.9 \times 10^{6}$ daltons compared to the values of $4.88 \times 10^{6}$ for A/Victoria RNA (Table 1) and $4.8 \times 10^{6}$ and $4.9 \times 10^{6}$ for the cDNAs of A/Victoria and FPV respectively (Table 3 ).

There is also the question of whether the sizes of the RNA in formamide and the single-strand cDNA contain sufficient information to encode the observed viral proteins. Consider, for example, the gene for the hemagglutinin. Inglis et al. (3) and Palese and Schulman (4) have shown by biochemical and genetic methods that the hemagglutinins of FPV and A/Hong Kong, an $\mathrm{H} 3 / \mathrm{N} 2$ strain like A/Victoria, are produced by gene $4 \mathrm{RNA}$. The sizes of these RNAs in formamide are estimated as 2060 and 1950 nucleotides for FPV and A/Victoria respectively while the CDNA sizes were 1940 and 1920 nucleotides respectively. If completely translated, these will produce a protein of 640-690 amino acids (70,000-75,000 daltons). Although the Influenza hemagglutinin from a number of strains has been examined and found to range from 75,000-85,000 daltons, a large proportion of this is carbohydrate. White (31) has estimated that HAl comprises about $60 \%$ of the viral carbohydrate and Ward and Dopheide (32) have shown that glycosylated proteins exhibit anomalously low electrophoretic mobility in SDS-polyacrylamide gels. Similar results have been reported (33) for the major Avian Myeloblastosis Virus glycoprotein. When this effect of carbohydrate content on mobility is accounted for, the apo-proteins HA1 and HA2 have molecular weights of 35,500 and 28,300 daltons respectively (32); this total of 63,800 daltons (580 amino acids) is thus easily contained in both RNA and cDNA molecules of the size reported here (Tables 1 and 3 ). We have also examined the RNA/protein relationships for the other genes and, as seen in Table 4, have found good agreement between them.

The results presented here also indicate that the cDNA is a faithful copy of the vRNA. Thus greater than $95 \%$ is protected from S1-nuclease by the template RNA (Table 1) and the kinetics of hybrid formation and melting are as expected (Fig. 7). We have found no evidence of "slippage" occurring at the oligo(dT) primer.

In conclusion, we have outlined a procedure for obtaining double-stranded DNA copies of Influenza RNA genes. Although initially covalently joined, the connecting linkage is susceptible to S1-nuclease (Fig. 9), yielding DNA (Fig. 
Table 4

\begin{tabular}{|c|c|c|c|c|}
\hline Protein & Virus & $\begin{array}{c}\mathrm{MW}^{\mathrm{S}} \\
\text { (daltons) }\end{array}$ & $\alpha \alpha^{*}$ & $\begin{array}{l}\text { Minimum number of } \\
\text { nucleotides } \\
\text { required in mRNA }\end{array}$ \\
\hline \multirow[t]{3}{*}{$\mathrm{P} 1-\mathrm{P} 3$} & \multirow{3}{*}{$\begin{array}{c}\text { A/Memphis } \\
\text { (A/Hong Kong } \\
\text { variant) }\end{array}$} & $81-94,000$ & $730-850$ & $2190-2560$ \\
\hline & & 35,500 & 320 & \multirow{2}{*}{1730} \\
\hline & & 28,300 & 257 & \\
\hline NP & FPV & $53-60,000$ & $480-540$ & $1440-1620$ \\
\hline NA & FPV & 45,000 & 410 & 1230 \\
\hline NA & $x-7$ & $58-66,000$ & $530-600$ & $1590-1800$ \\
\hline M & FPV & 25,000 & 230 & 690 \\
\hline NS & FPV & 23,000 & 210 & 630 \\
\hline
\end{tabular}

* Based on normal amino acid composition and an average molecular weight of 110 per amino acid.

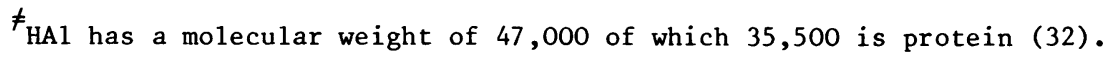

SS Molecular weights are taken from (31), except those for the hemagglutinin, which are from (32)

10) that can be cloned in plasmids using synthetic linkers (34) or "tailing" procedures (35). Finally, we have revised the sizes of the viral genes. The new estimates, based on migration of the RNA in $98 \%$ formamide gels and the cDNA on alkaline gels, indicate that the viral genes probably contain few nonessential nucleotides and thus make it unlikely that the genes contain untranslated inserts within the structural sequence.

\section{ACKNOWLEDGEMENTS}

We thank Hilary Watkins and Parmjit Jat for help with virus and enzyme preparations, and $\mathrm{Dr}$. A.J. Hale for provision of excellent research facilities. We are grateful to Anne Henry for typing the manuscript and John Hobbs for drafting graphical figures. 


\section{REFERENCES}

1. Andrewes, C. and Pereira, H.G. (1972). Viruses of Vertebrates, Third Edition, Bailliere Tindall, London, 205-222.

2. Hay, A.J., Lomniczi, B., Bellamy, A.R. and Skehel, J.J. (1977). Virology 83, 337-355.

3. Inglis, S.C., McGeoch, D.J. and Mahy, B.W.J. (1977). Virology 78, 522536.

4. Palese, P. and Schulman, J.L. (1976). Proc. Nat1. Acad. Sci. U.S.A. 73, 2142-2146.

5. Palese, P. (1977). Cel1 10, 1-10.

6. Almond, J.W., McGeoch, D. and Barry, R.D. (1977). Virology 81, 62-73.

7. Skehel, J.J. and Hay, A.J. (1978). Nucl. Acids Res. 5, 1207-1219.

8. Palmiter, R.D. (1974). Biochemistry 13, 3606-3615.

9. Kacian, D.L. and Spiegelman, S. (1973). In: L. Grosman and K. Moldave (eds.), Nucleic Acids and Protein Synthesis, Methods in Enzymology, vol. 29E, p. 150-173, Academic Press Inc., New York.

10. Sippe1, A.E. (1973). Eur. J. Biochem. 37, 31-40.

11. Vogt, V.M. (1973). Eur. J. Biochem. 33, 192-200.

12. Maniatis, T., Jeffrey, A. and Van de Sande, H. (1975). Biochemistry 14, 3787-3794.

13. Sharp, P.A., Sugden, B. and Sambrook, J. (1973). Biochemistry 12, 30553063.

14. McDone11, M.W., Simon, M.N. and Studier, F.W. (1977). J. Mol. Biol. 110, 119-146.

15. Smith, H.O. and Birnsteil, M.L. (1976). Nucl. Acids Res. 3, 2387-2398.

16. Maxam, A.M. and Gilbert, W. (1977). Proc. Nat1. Acad. Sci. U.S.A. 74, 560-564.

17. Southern, E.M. (1975). J. Mo1. Bio1. 98, 503-517.

18. Pons, M.W. (1976). Virology 69, 789-792.

19. McGeoch, D., Fellner, P. and Newton, C. (1976). Proc. Nat1. Acad. Sci. U.S.A. 73, 3045-3049.

20. Devos, R., Gillis, E. and Fiers, W. (1976). Eur. J. Biochem. 62, 401410.

21. Hay, A.J., Abraham, G., Skehe1, J.J., Smith, J.C. and Fe1lner, P. (1977). Nuc1. Acids Res. 4, 4197-4209.

22. Falvey, A.K., Kantov, J.A., Robert-Guroff, M.G., Picciano, D.J., Weiss, G.B., Vavich, J.M. and Anderson, W.F. (1974). J. Biol. Chem. 249, 70497056 .

23. Devos, R., van Emmelo, J., Celen, P., Gillis, E. and Fiers, W. (1977). Eur. J. Biochem. 79, 419-432.

24. Efstratiadis, A., Kafatos, F.C., Maxam, A.M. and Maniatis, T. (1976). Ce11 7, 279-288.

25. Monahan, J.J., McReynolds, L.A. and O'Malley, B.W. (1976). J. Biol. Chem. 251, 7355-7362.

26. Webster, R.G. and Laver, W.G. (1975). In: 'The Influenza Viruses and Influenza' (ed. E.D. Kilbourne), p. 269-314, Academic Press, New York.

27. Lehrach, H., Diamond, D., Wozney, J.M. and Boedtker, H. (1977). Biochemistry $16,4743-4751$.

28. Boedtker, H. (1971). Biochim. Biophys. Acta 240, 448-453.

29. Rejinders, L., Sloof, P., Sival, J. and Borst, P. (1973). Biochim. Biophys. Acta 324, 320-333. 